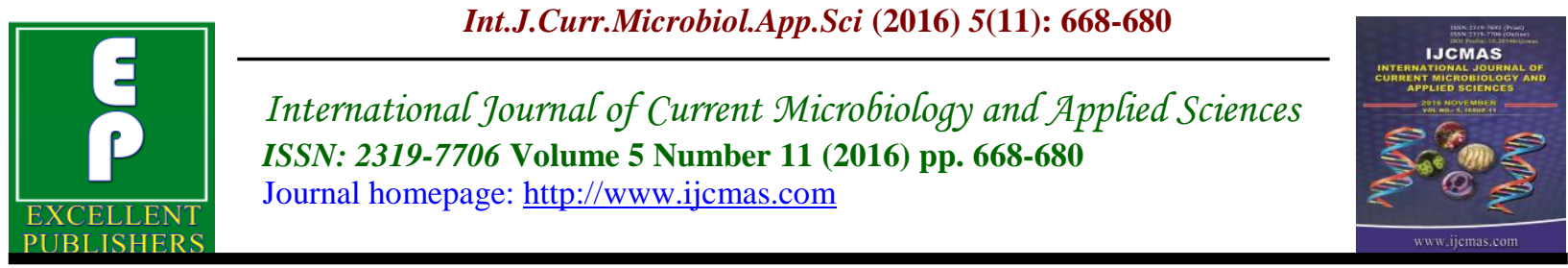

Original Research Article

http://dx.doi.org/10.20546/ijcmas.2016.511.078

\title{
Effect of Foliar Application with Humic Acid Substances under Nitrogen Fertilization Levels on Quality and Yields of Sugar Beet Plant
}

\author{
A.S. El-Hassanin ${ }^{1}$, M.R. Samak ${ }^{1}$, Moustafa, N. Shafika ${ }^{2}$, \\ A.M. Khalifa ${ }^{1}$ and M. Ibrahim Inas ${ }^{2 *}$ \\ ${ }^{1}$ Department of Natural Resources, Inst. of African Research and Studies, \\ Cairo University, Egypt \\ ${ }^{2}$ Department of Research of Physiology and Chemistry, Sugar Crops Res., \\ Inst., Agric. Res. Center, Egypt \\ *Corresponding author
}

\begin{tabular}{|c|c|}
\hline & \multirow{12}{*}{$\begin{array}{l}\text { Two field experiments were carried out at the experimental station of Sakha } \\
\text { Agricultural Research Station, Egypt during the two growing seasons of } 2013 / 2014 \\
\text { and } 2014 / 2015 \text { to study the effect of foliar application with humic acid, fulvic acid } \\
\text { and potassium humate at level } 0.5 \% \text {, and four soil application of nitrogen } \\
\text { fertilization rates }(36,52,73 \text { and } 90 \mathrm{kgN} / \text { fed.)on yield and quality of sugar beet. } \\
\text { Results showed that foliar application statistically improved sucrose, extractable } \\
\text { sugar, purity, sugar lost to molasses, extractability percentages and yield (tons/ fed) } \\
\text { in both seasons. Fulvic acid surpassed the other humic substances in the content of } \\
\text { sucrose, extractable sugar, and purity percentages; also yield, and lowest juice } \\
\text { impurities in both seasons. Decreasing nitrogen fertilization level from } 90 \mathrm{~kg} \mathrm{~N} / \mathrm{fed} \\
\text { to } 36 \mathrm{~kg} \mathrm{~N} / \mathrm{fed} \text { significantly decreased all traits in both seasons, except } \mathrm{K} \% \text { and } \\
\text { Na\% in } 2^{\text {nd }} \text { season. Applied N fertilization at level } 72 \mathrm{~kg} \mathrm{~N} / \mathrm{fed} \mathrm{significantly} \\
\text { maximized extractable sugar\%, extractability, also root and sugar yields (tons/ fed) } \\
\text { in both seasons. Application of } 72 \mathrm{Kg} \mathrm{N} / \mathrm{fed} \mathrm{with} \mathrm{fulvic} \mathrm{acid} \mathrm{helpful} \mathrm{for} \mathrm{suggesting} \\
\text { good use of nitrogen fertilizer along with fulvic acid to increase sugar beet crop } \\
\text { yield and improve its quality. }\end{array}$} \\
\hline \multirow{6}{*}{$\begin{array}{l}\text { Sugar beet- } \\
\text { Nitrogen- } \\
\text { Fertilization- } \\
\text { Humic substances- } \\
\text { yield-quality. }\end{array}$} & \\
\hline & \\
\hline & \\
\hline & \\
\hline & \\
\hline & \\
\hline Article Info & \\
\hline & \\
\hline & \\
\hline & \\
\hline & \\
\hline
\end{tabular}

\section{Introduction}

Nitrogen is referred to a balance wheel of sugar beet nutrition because of the fact that the efficiency of other nutrients is based on it. Many investigations have been oriented to optimize using of nitrogen through a better understanding of crop requirements under varying conditions of soil and climate. This is because nitrogen has a pronounced effect on growth where Attallah and El Etreiby (2002) found that root fresh weight was increased with increasing $\mathrm{N}$ levels.
EL-Geddawy et al., (2008) mentioned that nitrogen levels had a significant effect on purity $\%$ and reduced it; they also added that the drop in juice purity was due to the increase in amino compounds caused by the excessive N uptake. El-Sarag (2009) reported that increasing $\mathrm{N}$ levels increased root fresh weight. Ferweez et al., (2011) indicated that adding $\mathrm{N}$ fertilizer at 100 or110 kg N fed ${ }^{-1}$ caused an increase in root length by 8.58 and $11.32 \%$ and root 
diameter by 7.78 and $11.84 \%$ compared to addition of $80 \mathrm{~kg} \mathrm{~N}$ fed. Shaban et al., (2014) and Ali (2015) revealed that N levels significantly increased root length and diameter, as well as root, and top fresh weight, in addition to yield of root, top, biological, gross sugar, white sugar and loss sugar, also $\mathrm{K}, \mathrm{Na}$ and $\alpha$-amino $\mathrm{N} \%$, whereas harvest index was decreased.

Demand for sugar beet is increasing, thus growers are required to use additional nutrient inputs, especially mineral $\mathrm{N}$ to increase yield. Higher $\mathrm{N}$ application may result in $\mathrm{NO}_{2}$ pollution of groundwater Shrestha and Ladha, (1998), and soil acidification Kennedy and Tchan, (1992). Also, high $\mathrm{N} \%$ levels are increase identification resulting in higher emission of $\mathrm{N}_{2} \mathrm{O}$ to the atmosphere, which has a harmful impact on global warming (Bronson et al., 1997). These problems have renewed public interest in exploring alternate or supplementary nonpolluting sources of $\mathrm{N}$ for agriculture Ladha et al., (1997). Attention has therefore focused on substitute fertilizers, including organic sources such as humic acid substances.

Insignificant differences were observed on white sugar and its purity (\%). Humic substances can be subdivided into three major fractions: (1) Human, (2) Humic acid (HAs), and (3) Fulvic acid (FAs). These sub divisions are arbitrarily based on the solubility of each fraction in water adjusted to different acid alkaline ( $\mathrm{pH}$ levels) conditions. Humic compounds occupy a key position because of their multifarious roles in maintaining improving soil fertility and positively affecting physiological functions (both of soil biota as well as plants). Plenty of information is available on the beneficial effect of organic matter and especially humic compounds in the soil-plant system (Nardi et al., 2002; Arancon et al., 2006;
Campitelli et al., 2006; Steinberg et al., 2008; Khaled and Fawy, 2011). Bowen and Rovira (1999) explained that rhizobacteria, specifically plant hormone producing rhizosphere bacteria, in conjunction with humic and fulvic acids will supply plant growth promoting hormones to stimulate root and general plant growth via improved water and nutrient utilization from the soil solution. Humic and fulvic acids, preparations were reported to increase the uptake of mineral elements Mackowiak et al., (2001), to promote the root length Canellas et al., (2002), and to increase the fresh and dry weights of crop plants Chen et al., (2004a,b). Humicacid (HA) is one of the natural antioxidants. The absorption of humic substances into the plant tissue resulting in various biochemical effects through elevating the nutrient uptake and maintaining vitamins and amino acid level in plant tissues. Humic acid is used widely across the globe by agriculturists due to its several benefits i.e., stimulates the respiration rates, increases root, shoot growth, fresh and dry weight enhancement of plant root uptake of $\mathrm{P}, \mathrm{K}, \mathrm{Fe}, \mathrm{Cu}, \mathrm{Zn}$ and $\mathrm{Ca}$, and plant enzymes and hormones. More ever, it suppresses diseases, heat stress and frost damage by promoting antioxidant activity (El-Bassiouny Hala et al., 2014and Syedabadi and Armin 2014). Due to the positive effect of humic substances on the visible growth of plants, these chemicals have been widely used by the growers instead of other substances such as pesticides, etc. this, however, has led to growers using higher amounts of these substances. Fulvic acid has a much smaller molecular weight, and is more biologically active. In addition not only it doesn't surrounds mineral ions, but it can also help transport them through the cell membrane and release them inside the cell. This means that fulvic acid makes a great foliar spray, allowing trace elements such as copper, iron, 
manganese and zinc to be better absorbed through the leaves. Fulvic acid also stimulates the metabolisms of plants, which makes fulvic acid treatments a great way to quickly correct trace metal deficiencies while stimulating plant growth by Harley, 2015.

The main objective of this study was tominimize the environmental pollution which resulted from mineral fertilizers by using organic fertilization.

\section{Materials and Methods}

Two experiments were carried out in (20132014 and 2014-2015) seasons at Sakha Agricultural Research Station, KafrELSheikh Governorate, Egypt to study the effect of foliar application by some humic acid substances under various levels of nitrogen fertilization on sugar beet quality and yields. Soil of the experimental area, was prepared for some physical and chemical analysis before sowing and after harvest for both studied seasons according to Chapman and Pratt (1961), and the description was given in Table (1).This study included sixteen treatments which were the combination of four humic acid substances (control, Humic acid, Fulvic acid and Potassium humate) as foliar application at level $8 \mathrm{mg} / \mathrm{L}$ sprayed twice at 45 and 75 days after sowing and four soil applications of nitrogen fertilization rates of $36,54,72$ and $90 \mathrm{kgN} / \mathrm{fed}$. Treatments were arranged in a split plot design with three replications. Spraying foliage by humic acid substances allocated in the main plots, whereas, the four nitrogen rates were randomly distributed in the sub plots. The plot area was $21 \mathrm{~m}^{2}$ included six ridges of $50 \mathrm{~cm}$ apart and 7 meter in length. Sugar beet seeds (Beta vulgaris, L.) variety Sultan was sown in hills of $20 \mathrm{~cm}$ apart in the $1^{\text {st }}$ week of October in both seasons. Nitrogen fertilizer was added as urea $(46 \% \mathrm{~N})$ in two equal splits i.e. after thinning (45days after sowing) and 4 weeks later at the above mentioned rates. Potassium fertilizer at rate $\left(48 \mathrm{~kg} \mathrm{~K}_{2} \mathrm{O} /\right.$ fad.) was added as potassium sulfate of $48 \% \mathrm{~K}_{2} \mathrm{O}$ with the $1^{\text {st }}$ dose of nitrogen. However, phosphorus was applied as calcium superphosphate $\left(15.5 \% \mathrm{P}_{2} \mathrm{O}_{5}\right), 30 \mathrm{~kg}$ $\mathrm{P}_{2} \mathrm{O}_{5} /$ fed at seed bed preparation. Other agricultural practices were carried out as recommended for growing sugar beet.

At harvest, the three guarded central rows of each plot were harvested to estimate juice quality and root yield from random five plants:

\section{Juice quality}

All parameters were determined in Delta Sugar Company Limited Laboratories at ElHamoul, Kafr El-Sheikh Governorate according to the method of McGinnus (1971).

-Impurities percentages $(\mathrm{K} \%, \mathrm{Na} \%$ and $\alpha$ amino-N \%)

- Some technological traits, i.e. sucrose\%, purity $\%$, extractable sugar extractability $\%$, alkalinity coefficient, SLM.

- Root yield (ton/fed.) and sugar yield (ton/fed.).

Where Sugar yield (ton/fed.,) = extractable sugar $\times$ root yield (ton/fed.).

The obtained data of the two seasons were computed and subjected to the proper statistical analysis of split plot design according to Snedecor and Cochran, (1980), and the treatments means were compared using the least significant difference (LSD) at 5 level of significance was used. 


\section{Results and Discussion}

Juice impurities contents $(\mathrm{K}, \mathrm{Na}$ and $\alpha$ amino-N \%):

Data illustrated in Table (2) indicated that foliar spraying application with humic substances significantly affected the content of $\mathrm{K}, \mathrm{Na}$ and $\alpha$-amino-N\% in both seasons. This result may be ascribed to the possibility that humic substances may enhance the uptake of some nutrients. Another reason may be related to plants absorption of more elements due to better developed root system by addition of humic substances, David et al., (1994). Foliar application with fulvic acid recorded the lowest values for $\mathrm{K}$ and $\mathrm{Na} \%$, while spraying $\mathrm{K}$ - humate gave the lowest $\alpha$-amino-N\% compared the other humic acid substances in both seasons.

The increment of $\mathrm{N}$ levels up to $90 \mathrm{kgN} / \mathrm{fed}$ significantly increased juice impurities contents $(\mathrm{K}$ and $\mathrm{Na} \%)$ in the $1^{\text {st }}$ season only and $\alpha$-amino-N (\%) in both seasons, Table (2).This was anticipated since high nitrogen levels enhance vegetative growth and consequently absorption of other nutrients to meet the growth demand. These results are in accordance with those obtained by Mehran and Samad (2013); they indicated that the contents of $\mathrm{N}$ and $\mathrm{K}$ in the root of sugar beet were significantly increased by increasing $\mathrm{N}$ - fertilizer levels over the two growing seasons.

The interaction effect between foliar application with humic substances and mineral nitrogen fertilizer rates had a significant effect on $\mathrm{K}, \mathrm{Na}$ and $\alpha$-amino- $\mathrm{N}$ $\%)$ in the $1^{\text {st }}$ and $2^{\text {nd }}$ seasons. The lowest interaction values were obtained by applying8mg of fulvic acid/ $\mathrm{L}$ and $72 \mathrm{kgN} /$ fed for $\mathrm{K}$ and $\mathrm{Na} \%$ in the $1^{\text {st }}$ season and $\alpha$ amino-N (\%) in the $2^{\text {nd }}$ season. In this regard, Armstrong and Milford (1985) interpreted this behavior to the large amounts of $\mathrm{N}$ mineralization either from soils inherently rich in organic matter or from recently added manures.

\section{Sucrose, extractable sugar and purity}

Data presented in Table (3) revealed that the evaluated humic acid substances as foliar application differed significantly in their concentration of Sucrose, extractable sugar and purity in sugar beet roots grown over two seasons. Fulvic acid surpassed over humic acid and potassium humate, which recorded the highest sucrose, extractable sugar and purity in both seasons.

Data presented in Table (3) showed that soil application by inorganic N-fertilizer (ten/fed) significantly increased these traits in the $1^{\text {st }}$ and $2^{\text {nd }}$ seasons. Insignificant difference was obtained between $\mathrm{N}$-fertilizer levels applied at 90 and $72 \mathrm{~kg} \mathrm{~N} /$ fed in their effect on sucrose, extractable sugar and purity in both seasons. So; nitrogen level at $72 \mathrm{~kg}$ / fed significantly maximized sucrose, extractable sugar and also juice purity percentages in both seasons. The positive effect of $\mathrm{N}$ - fertilizer on sucrose values might be attributed to the increased efficiency of nitrogen fertilization in building up metabolites translocations from leaves to developing roots thus increases sucrose accumulation in sugar beet roots Ramadan (2015).

The interaction effect between humic substances and mineral nitrogen rates (Table3) revealed a significant effect on sucrose, extractable sugar as well as purity in the two seasons The highest values of these traits were obtained by spraying foliage of sugar beet with fulvic acid and fertilized by nitrogen at $72 \mathrm{~kg} / \mathrm{fed}$ in both 2013/2014 and 2014/2015seasons. 
Sugar lost in molasses, alkalinity coefficient and extractability

Humic acid substances as foliar application beside mineral nitrogen levels individually and, or in combination insignificantly affected on alkalinity coefficient percentage in the two growing seasons. In general, foliar application by humic substances decreased sugar lost in molasses\%, while it increased extractability\% in both seasons. This could be due to its effect in decreasing $\mathrm{K}$ and $\alpha$-amino-N, and also increasing extractable sugar (Tables, 2 and 3). Regarding the effect of humic acid substances as foliar application on \% sugar lost in molasses and extract ability, this is substantially evident from data of Table (4) and extractability \%, where fulvic acid recorded the lowest sugar lost in molasses\%, as the wells as highest extractability\% compared to control in both seasons.
Data presented in Table (4) revealed that increasing nitrogen fertilizer levels up to 90 $\mathrm{kg} / \mathrm{fed}$ significantly increased sugar lost in molasses, while it significantly decreased extractability \%. Decreasing nitrogen fertilizer levels from 90 to $72 \mathrm{~kg} / \mathrm{fed}$ insignificantly affected both sugar lost in molasses and extractability\% in the $1^{\text {st }}$ and $2^{\text {nd }}$ seasons. This result agrees with those reported by Shafika (2006). As for the interaction effect it is clear from data show in Table (4) that the interaction between humic acid substances and nitrogen fertilizer levels possessed a significant decrease on sugar lost in molasses and reversely a significant increase on extractability\% (Fig.1) for the two seasons. Fulvic acid as a foliar application and nitrogen fertilizer level applied at $72 \mathrm{~kg} / \mathrm{fed}$ decreased sugar lost in molasses by $11.03 \%$ and $11.04 \%$. Meanwhile, it increased extractability\% by $2.17 \%$ and $1.74 \%$, respectively in both seasons.

Table.1 Soil analysis before sowing and at harvest (the average of the two growing seasons).

\begin{tabular}{|c|c|c|c|c|c|c|c|c|c|c|}
\hline \multicolumn{11}{|c|}{ Before Sowing } \\
\hline \multicolumn{8}{|c|}{ Mechanical analysis } & \multirow{2}{*}{$\begin{array}{l}\text { SP } \\
\%\end{array}$} & \multirow{2}{*}{$\begin{array}{c}\text { EC } \\
(\mathrm{ds} / \mathrm{m})\end{array}$} & \multirow{2}{*}{$\begin{array}{c}\text { PH } \\
1: 2.5\end{array}$} \\
\hline \multicolumn{2}{|c|}{ Texture } & \% Clay & $\%$ Silt & \multicolumn{2}{|c|}{$\%$ Fine sand } & \multicolumn{2}{|c|}{$\%$ coarse sand } & & & \\
\hline \multicolumn{2}{|c|}{ Salty clay } & 39.3 & 39.0 & \multicolumn{2}{|c|}{16.2} & \multicolumn{2}{|c|}{5.5} & 43.3 & 1.50 & 7.49 \\
\hline \multicolumn{11}{|c|}{ Chemical analysis for paste soil } \\
\hline \multicolumn{4}{|c|}{ Soluble cations (meq/ L) } & \multicolumn{4}{|c|}{ Soluble anions (meq/ L) } & $\begin{array}{c}\text { OM } \\
\%\end{array}$ & \multicolumn{2}{|c|}{$\begin{array}{c}\text { Available } \mathbf{N}(\mathrm{mg} / \mathrm{kg} \\
\text { soil) }\end{array}$} \\
\hline $\mathbf{K}^{+}$ & $\mathrm{Na}^{+}$ & $\mathbf{M g}^{++}$ & $\mathbf{C a}^{++}$ & $\mathrm{So}_{4}=$ & $\mathrm{Cl}^{-}$ & $\mathrm{HcO}_{3}^{-}$ & $\mathrm{Co}_{3}=$ & \multirow{2}{*}{1.1} & \multirow{2}{*}{\multicolumn{2}{|c|}{0.13}} \\
\hline 0.45 & 1.10 & 1.40 & 3.00 & 2.16 & 1.00 & 2.79 & - & & & \\
\hline \multicolumn{11}{|c|}{ After harvesting } \\
\hline \multicolumn{8}{|c|}{ Mechanical analysis } & \multirow{2}{*}{$\begin{array}{c}\text { SP } \\
\%\end{array}$} & \multirow{2}{*}{$\begin{array}{c}\text { EC } \\
(\mathrm{ds} / \mathrm{m}) \\
\end{array}$} & \multirow{2}{*}{$\begin{array}{c}\text { PH } \\
1: 2.5\end{array}$} \\
\hline \multicolumn{2}{|c|}{ Texture } & \% Clay & $\%$ Silt & \multicolumn{2}{|c|}{$\%$ Fine sand } & \multicolumn{2}{|c|}{$\%$ coarse sand } & & & \\
\hline \multicolumn{2}{|c|}{ Silty clay } & 36.4 & 38.4 & \multicolumn{2}{|c|}{20.1} & \multicolumn{2}{|c|}{5.30} & 49.00 & 1.64 & 7.99 \\
\hline \multicolumn{11}{|c|}{ Chemical analysis for paste soil } \\
\hline \multicolumn{4}{|c|}{ Soluble cations (meq/ L) } & \multicolumn{4}{|c|}{ Soluble anions (meq/ L) } & OM \% & \multicolumn{2}{|c|}{$\begin{array}{c}\text { Available } \mathbf{N}(\mathrm{mg} / \mathrm{kg} \\
\text { soil) }\end{array}$} \\
\hline $\mathbf{K}^{+}$ & $\mathrm{Na}^{+}$ & $\mathbf{M g}^{++}$ & $\mathbf{C a}^{++}$ & $\mathrm{So}_{4}{ }^{=}$ & $\mathrm{Cl}^{-}$ & $\mathrm{HCO}_{3}^{-}$ & $\mathrm{Co}_{3}{ }^{=}$ & \multirow{2}{*}{1.32} & \multirow{2}{*}{\multicolumn{2}{|c|}{0.25}} \\
\hline 0.63 & 1.40 & 1.64 & 3.86 & 3.04 & 1.39 & 3.10 & - & & & \\
\hline
\end{tabular}


Table. 2 Effect of humic acid substances on juice impurities percentage (K, Na and $\alpha$-amino-N \%) of sugar beet roots in (2013/ 2014 and 2014/ 2015) seasons

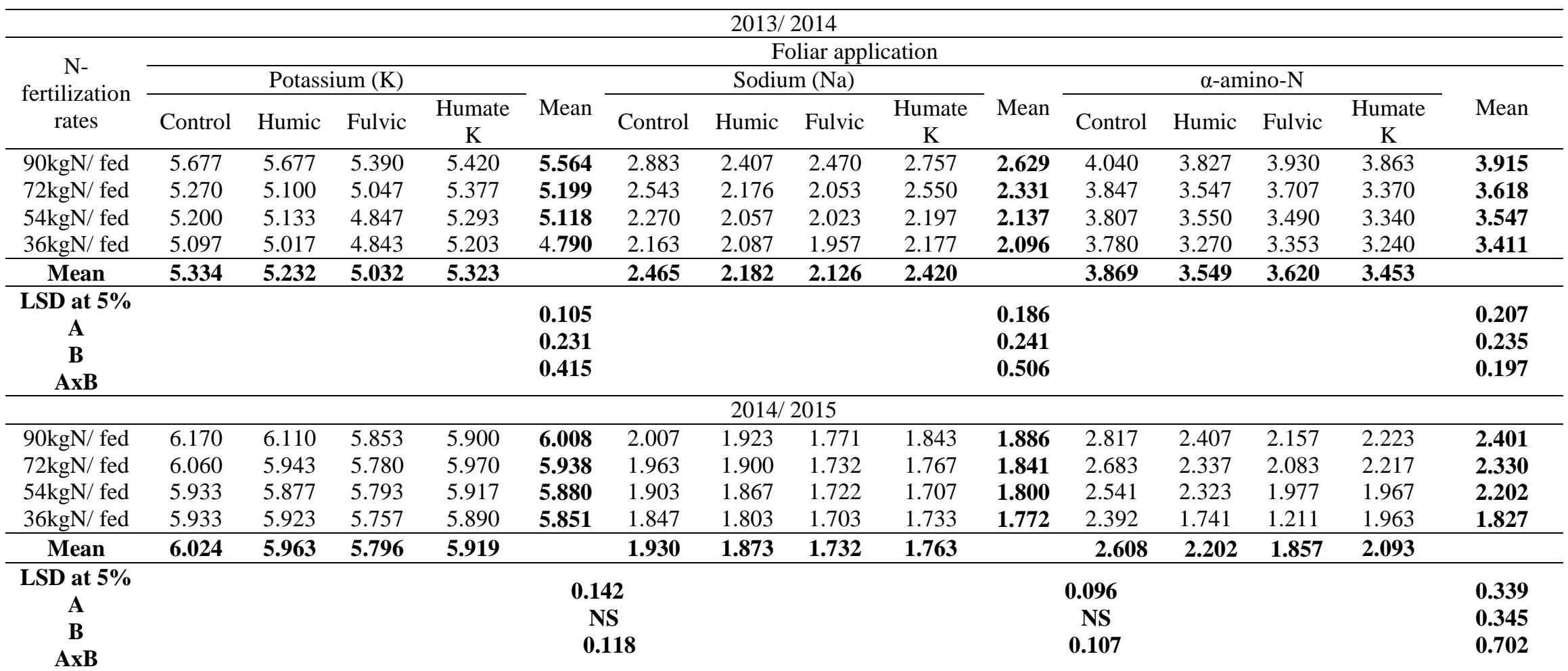


Table.3 Effect of humic acid substances on sucrose, Ex. S. and $\alpha$-amino-N \% of sugar beet roots in (2013/ 2014 and 2014/ 2015) seasons

\begin{tabular}{|c|c|c|c|c|c|c|c|c|c|c|c|c|c|c|c|}
\hline \multicolumn{16}{|c|}{$2013 / 2014$} \\
\hline \multirow{3}{*}{$\begin{array}{l}\text { N-fertilization } \\
\text { rates }\end{array}$} & \multicolumn{15}{|c|}{ Foliar application } \\
\hline & \multicolumn{4}{|c|}{ Sucrose $(\mathrm{S} \%)$} & \multirow[b]{2}{*}{ Mean } & \multicolumn{4}{|c|}{ Extractable sugar (Ex. S \%) } & \multirow[b]{2}{*}{ Mean } & \multicolumn{4}{|c|}{ Purity $(\mathrm{P} \%)$} & \multirow[b]{2}{*}{ Mean } \\
\hline & Control & Humic & Fulvic & $\begin{array}{c}\text { Humate } \\
\mathrm{K}\end{array}$ & & Control & Humic & Fulvic & $\begin{array}{c}\text { Humate } \\
\mathrm{K}\end{array}$ & & Control & Humic & Fulvic & $\begin{array}{c}\text { Humate } \\
\mathrm{K}\end{array}$ & \\
\hline $90 \mathrm{kgN} / \mathrm{fed}$ & 20.94 & 20.94 & 21.42 & 20.94 & 21.06 & 17.62 & 17.75 & 18.24 & 17.73 & $\mathbf{1 7 . 8 3}$ & 90.71 & 91.24 & 91.51 & 91.16 & 91.14 \\
\hline $72 \mathrm{kgN} / \mathrm{fed}$ & 20.69 & 20.74 & 21.39 & 20.87 & 20.92 & 17.53 & 17.73 & 18.37 & 17.82 & 17.86 & 91.32 & 91.91 & 92.15 & 91.64 & 91.75 \\
\hline $54 \mathrm{kgN} / \mathrm{fed}$ & 19.85 & 20.95 & 20.85 & 20.77 & 20.61 & 16.75 & 17.96 & 17.92 & 17.79 & 17.60 & 91.25 & 92.04 & 92.27 & 91.92 & 91.87 \\
\hline $36 \mathrm{kgN} / \mathrm{fed}$ & 18.76 & 20.25 & 20.81 & 20.63 & 20.11 & 15.70 & 17.34 & 17.92 & 17.69 & 17.16 & 90.96 & 92.05 & 92.40 & 92.01 & 92.03 \\
\hline Mean & 20.04 & 20.72 & 21.12 & 20.80 & & 16.88 & 17.73 & 18.12 & 17.76 & & 91.06 & 91.81 & 92.08 & 91.68 & \\
\hline LSD at $5 \% \mathrm{~A}$ & & & & & 0.61 & & & & & 1.12 & & & & & 0.51 \\
\hline B & & & & & 0.33 & & & & & 0.45 & & & & & 0.55 \\
\hline $\mathbf{A x B}$ & & & & & 1.04 & & & & & 0.86 & & & & & 0.73 \\
\hline \multicolumn{16}{|c|}{$2014 / 2015$} \\
\hline $90 \mathrm{kgN} / \mathrm{fed}$ & 21.08 & 21.62 & 21.36 & 21.38 & 21.36 & 18.13 & 18.79 & 18.65 & 18.64 & 18.55 & 91.92 & 92.47 & 92.83 & 92.71 & 92.48 \\
\hline $72 \mathrm{kgN} / \mathrm{fed}$ & 21.08 & 21.59 & 21.39 & 21.35 & 21.33 & 18.19 & 18.81 & 18.72 & 18.61 & 18.58 & 92.11 & 92.63 & 92.96 & 92.71 & 92.60 \\
\hline $54 \mathrm{kgN} / \mathrm{fed}$ & 20.37 & 21.56 & 21.28 & 21.21 & 21.11 & 17.54 & 18.80 & 18.63 & 18.55 & 18.38 & 92.09 & 92.70 & 92.99 & 92.91 & 92.67 \\
\hline $36 \mathrm{kgN} / \mathrm{fed}$ & 20.54 & 21.49 & 21.03 & 21.17 & 21.06 & 17.75 & 18.87 & 18.58 & 18.51 & 18.43 & 92.29 & 93.07 & 93.48 & 92.90 & 92.94 \\
\hline Mean & 20.77 & 21.57 & 21.27 & 21.28 & & 17.90 & 18.82 & 18.65 & 18.58 & & 92.10 & 92.72 & 93.06 & 92.81 & \\
\hline LSD at $5 \% \mathrm{~A}$ & & & & & 0.43 & & & & & 0.35 & & & & & 0.46 \\
\hline B & & & & & 0.21 & & & & & 0.11 & & & & & 0.39 \\
\hline$A \times B$ & & & & & 0.65 & & & & & 0.58 & & & & & 0.56 \\
\hline
\end{tabular}


Table.4 Effect of humic acid substances on SLM, AC and Ex\% of sugar beet in (2013/ 2014 and 2014/ 2015) seasons

\begin{tabular}{|c|c|c|c|c|c|c|c|c|c|c|c|c|c|c|c|}
\hline \multicolumn{16}{|c|}{$2013 / 2014$} \\
\hline \multirow{3}{*}{$\begin{array}{l}\text { N-fertilization } \\
\text { rates }\end{array}$} & \multicolumn{15}{|c|}{ Foliar application } \\
\hline & \multicolumn{4}{|c|}{ Sugar lost to molasses (SLM\%) } & \multirow[b]{2}{*}{ Mean } & \multicolumn{4}{|c|}{ Alkalinity Coefficient (AC\%) } & \multirow[b]{2}{*}{ Mean } & \multicolumn{4}{|c|}{ Extractability (Ex\%) } & \multirow[b]{2}{*}{ Mean } \\
\hline & Control & Humic & Fulvic & $\begin{array}{c}\text { Humate } \\
\mathrm{K}\end{array}$ & & Control & Humic & Fulvic & $\begin{array}{c}\text { Humate } \\
\text { K }\end{array}$ & & Control & Humic & Fulvic & $\begin{array}{c}\text { Humate } \\
\mathrm{K}\end{array}$ & \\
\hline $90 \mathrm{kgN} / \mathrm{fed}$ & 2.721 & 2.589 & 2.583 & 2.611 & 2.626 & 2.141 & 2.112 & 2.000 & 2.117 & 2.093 & 84.14 & 84.77 & 85.14 & 84.67 & 84.66 \\
\hline $72 \mathrm{kgN} / \mathrm{fed}$ & 2.556 & 2.405 & 2.421 & 2.452 & 2.458 & 2.031 & 2.051 & 1.915 & 2.352 & 2.087 & 84.75 & 85.51 & 85.88 & 85.37 & $\mathbf{8 5 . 3 8}$ \\
\hline $54 \mathrm{kgN} / \mathrm{fed}$ & 2.498 & 2.394 & 2.334 & 2.384 & 2.402 & 1.962 & 2.025 & 1.968 & 2.243 & 2.050 & 84.40 & 85.71 & 85.93 & 85.64 & 85.42 \\
\hline $36 \mathrm{kgN} / \mathrm{fed}$ & 2.461 & 2.312 & 2.290 & 2.343 & 2.352 & 1.921 & 2.172 & 2.028 & 2.278 & 2.100 & 83.68 & 85.62 & 86.11 & 85.73 & 85.46 \\
\hline Mean & 2.559 & 2.425 & 2.407 & 2.447 & & 2.014 & 2.090 & 1.978 & 2.247 & & 84.24 & 85.40 & 85.76 & 85.35 & \\
\hline LSD at 5\% A & & & & & 0.083 & & & & & NS & & & & & 0.43 \\
\hline B & & & & & 0.175 & & & & & NS & & & & & 0.75 \\
\hline AxB & & & & & 0.265 & & & & & NS & & & & & 0.56 \\
\hline \multicolumn{16}{|c|}{$2014 / 2015$} \\
\hline $90 \mathrm{kgN} / \mathrm{fed}$ & 2.329 & 2.226 & 2.107 & 2.140 & 2.205 & 2.903 & 3.337 & 3.535 & 3.483 & 3.314 & 86.01 & 86.93 & 87.33 & 87.19 & 86.86 \\
\hline $72 \mathrm{kgN} / \mathrm{fed}$ & 2.294 & 2.182 & 2.072 & 2.137 & 2.172 & 2.990 & 3.356 & 3.606 & 3.490 & 3.361 & 86.27 & 87.11 & 87.51 & 87.18 & 87.02 \\
\hline $54 \mathrm{kgN} / \mathrm{fed}$ & 2.232 & 2.165 & 2.046 & 2.059 & 2.126 & 3.084 & 3.334 & 3.801 & 3.876 & 3.524 & 86.10 & 87.18 & 87.56 & 87.46 & 87.07 \\
\hline $36 \mathrm{kgN} / \mathrm{fed}$ & 2.187 & 2.017 & 1.847 & 2.058 & 2.027 & 3.253 & 4.438 & 6.160 & 3.883 & 4.433 & 86.43 & 87.82 & 88.36 & 87.44 & 87.52 \\
\hline Mean & 2.266 & 2.148 & 2.018 & 2.099 & & 3.058 & 3.616 & 4.276 & 3.683 & & 86.20 & 87.26 & 87.69 & 87.32 & \\
\hline LSD at 5\% A & & & & & 0.106 & & & & & NS & & & & & 0.37 \\
\hline $\begin{array}{c}\text { B } \\
\mathbf{A x B}\end{array}$ & & & & & $\begin{array}{l}0.153 \\
0.241\end{array}$ & & & & & NS & & & & & 0.94 \\
\hline
\end{tabular}


Table.5 Effect of humic acid substances on top, roots and sugar yields (tons/ fed) of sugar beet roots in (2013/ 2014 and 2014/2015) seasons

\begin{tabular}{|c|c|c|c|c|c|c|c|c|c|c|c|c|c|c|c|}
\hline \multicolumn{16}{|c|}{$2013 / 2014$} \\
\hline \multirow{3}{*}{$\begin{array}{l}\mathrm{N} \text {-fertilization } \\
\text { rates }\end{array}$} & \multicolumn{15}{|c|}{ Foliar application } \\
\hline & \multicolumn{4}{|c|}{ Top yield (tons/ fed) } & \multirow[b]{2}{*}{ Mean } & \multicolumn{4}{|c|}{ Root yield tons/ fed) } & \multirow[b]{2}{*}{ Mean } & \multicolumn{4}{|c|}{ Sugar yield/(tons/ fed) } & \multirow[b]{2}{*}{ Mean } \\
\hline & Control & Humic & Fulvic & $\begin{array}{c}\text { Humate } \\
\text { K }\end{array}$ & & Control & Humic & Fulvic & Humate $\mathrm{K}$ & & Control & Humic & Fulvic & Humate $\mathrm{K}$ & \\
\hline $90 \mathrm{kgN} / \mathrm{fed}$ & 7.222 & 8.232 & 10.04 & 7.692 & 8.297 & 23.61 & 26.46 & 32.06 & 27.94 & 27.52 & 4.160 & 4.697 & 5.847 & 4.954 & 4.914 \\
\hline $72 \mathrm{kgN} / \mathrm{fed}$ & 7.231 & 7.461 & 9.114 & 8.448 & 8.064 & 22.57 & 26.23 & 28.17 & 24.51 & 25.37 & 3.958 & 4.652 & 5.175 & 4.367 & 4.538 \\
\hline $54 \mathrm{kgN} / \mathrm{fed}$ & 7.202 & 7.201 & 8.435 & 7.447 & 7.571 & 20.75 & 25.43 & 25.31 & 21.11 & 23.15 & 3.476 & 4.566 & 4.534 & 3.755 & 4.083 \\
\hline $36 \mathrm{kgN} / \mathrm{fed}$ & 6.623 & 7.038 & 7.645 & 7.266 & 7.143 & 20.17 & 21.20 & 21.77 & 20.74 & 20.97 & 3.166 & 3.676 & 3.901 & 3.668 & 3.603 \\
\hline Mean & 7.070 & 7.483 & 8.809 & 7.713 & & 21.78 & 24.83 & 26.83 & 23.58 & & 3.690 & 4.398 & 4.864 & 4.186 & \\
\hline LSD at 5\% A & & & & & 0.613 & & & & & 0.76 & & & & & 0.401 \\
\hline B & & & & & 1.247 & & & & & 4.25 & & & & & 1.172 \\
\hline $\mathbf{A x B}$ & & & & & 1.615 & & & & & 4.41 & & & & & 0.913 \\
\hline \multicolumn{16}{|c|}{$2014 / 2015$} \\
\hline $90 \mathrm{kgN} / \mathrm{fed}$ & 7.133 & 7.333 & 7.867 & 7.333 & 7.417 & 22.53 & 22.83 & 23.47 & 23.07 & 22.90 & 4.085 & 4.291 & 4.378 & 4.300 & 4.263 \\
\hline $72 \mathrm{kgN} / \mathrm{fed}$ & 6.533 & 6.933 & 7.467 & 7.733 & 7.167 & 20.67 & 22.27 & 23.47 & 22.81 & 22.31 & 3.759 & 4.188 & 4.393 & 4.246 & 4.147 \\
\hline $54 \mathrm{kgN} / \mathrm{fed}$ & 6.533 & 6.667 & 7.467 & 7.200 & 6.967 & 20.53 & 21.87 & 21.23 & 21.07 & 21.18 & 3.600 & 4.110 & 3.956 & 3.909 & 3.894 \\
\hline $36 \mathrm{kgN} / \mathrm{fed}$ & 5.867 & 6.267 & 7.067 & 6.933 & 6.534 & 20.13 & 21.61 & 21.73 & 20.67 & 21.04 & 3.574 & 4.078 & 4.038 & 3.826 & 3.879 \\
\hline Mean & 6.517 & 6.800 & 7.467 & 7.300 & & 20.97 & 22.15 & 22.48 & 21.91 & & 3.755 & 4.167 & 4.191 & 4.070 & \\
\hline LSD at 5\% A & & & & & 0.562 & & & & & 0.83 & & & & & 0.235 \\
\hline B & & & & & 0.652 & & & & & 0.81 & & & & & 0.271 \\
\hline$A \times B$ & & & & & 1.034 & & & & & 1.13 & & & & & 0.394 \\
\hline
\end{tabular}


Fig.1 Effect of humic acid substances on extractability (\%) of sugar beet.
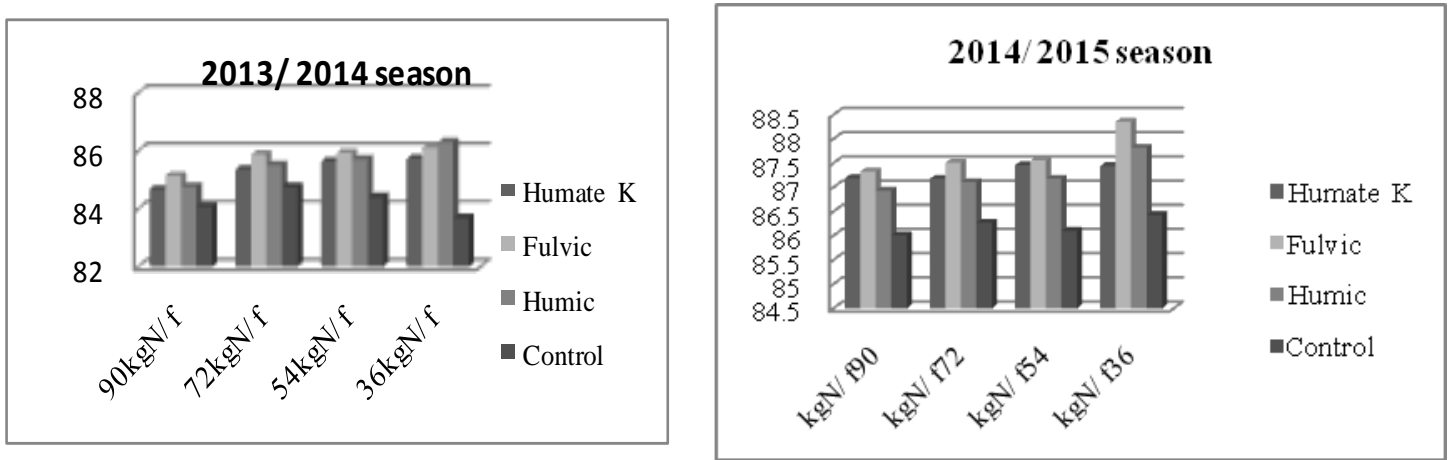

Fig.2 Effect of humic acid substances on root yield of sugar beet(tons/ fed)
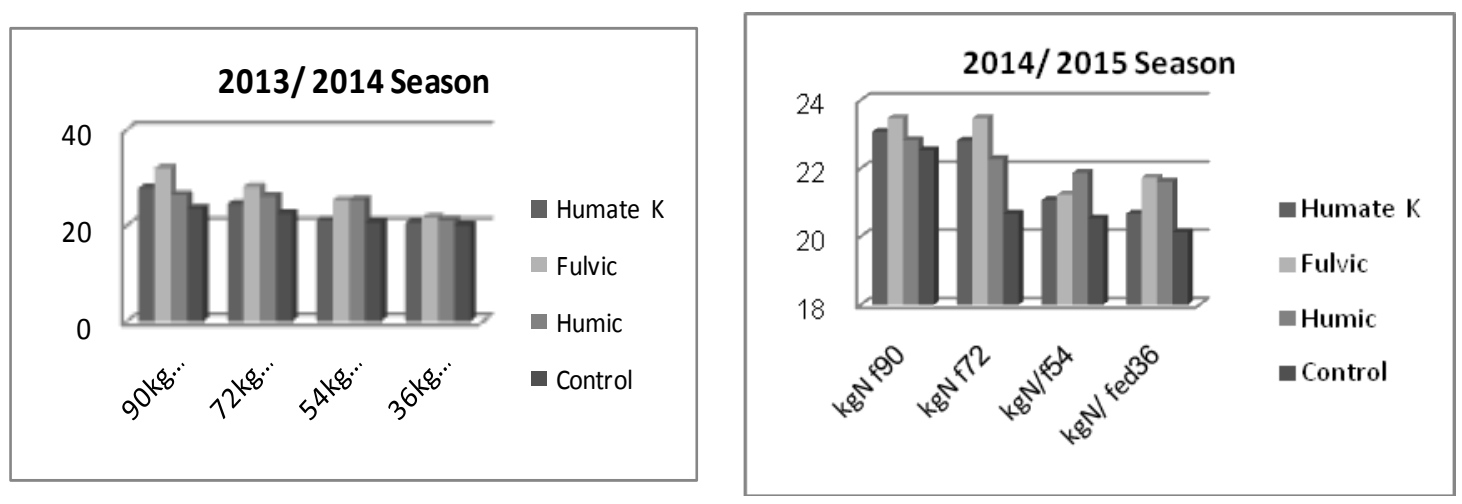

Fig.3 Effect of humicacid substances on sugar yield of sugar beet(tons/ fed).
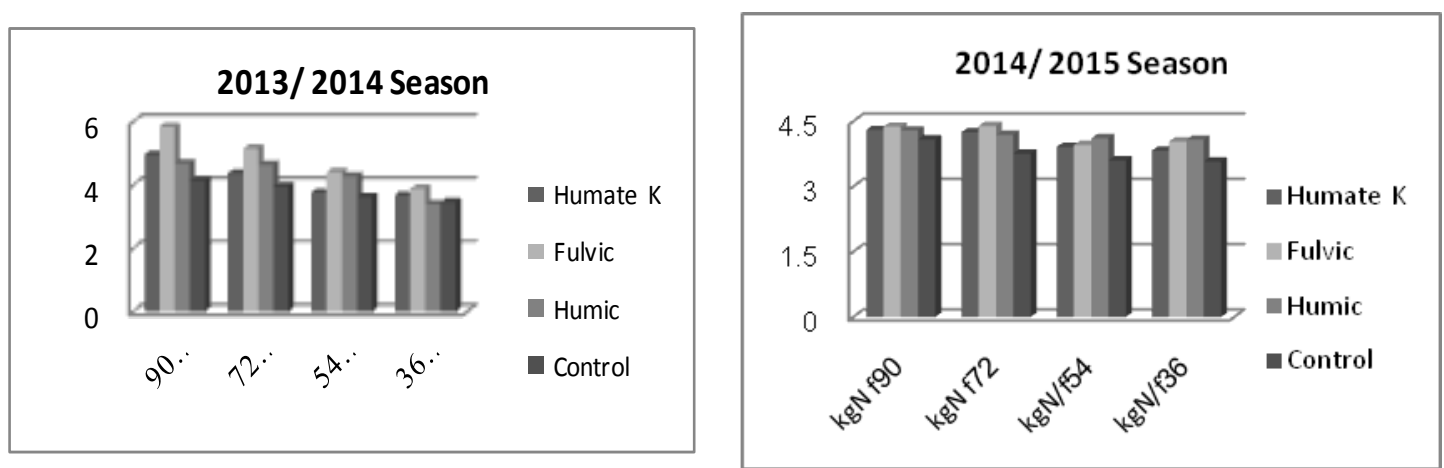


\section{Yields of top root and sugar}

Evidentially, data predicted In Table (5) and Figs. (2 \&3) revealed that foliar application with humic substances significantly increased top, root and sugar yields (tons/ fed) compared with those untreated in both seasons. This could be attributed to the influence related to fulvic acid application to plant foliage which affects the process of translocation of trace elements directly to metabolic sites in plant cell and thus maximizing the plants productive capacity. These results coincided with those found by Kabeel et al., (2008) as they showed that humic substances improve nutrient uptake, increase chlorophyll synthesis, better seed germination, increase fertilizer retention, stimulate beneficial microbial activity and produce healthier plants and improve yield. Meanwhile, Hye (2014) demonstrated that foliar application of fulvic acid at $0.8 \mathrm{~g} \mathrm{~L}^{-}$ could be used to promote plant growth and increase marketable yield in tomato production. In this respect, Eisa, Salwa (2011) and Ibrahim Dina et al., (2013) revealed that, foliar application with humic acid increased sugar yield of sugar beet.

Also, the same data presented in Tabled (5) and Figs. (2\&3) showed that top, root and sugar yields (tons/ fed) were significantly increased by $\mathrm{N}$ - fertilizer application. The treatment of $72 \mathrm{~kg} /$ fed significantly surpassed the other levels in both levels. According to these results, it is worthy to mention that increasing top, root and sugar yields with increasing $\mathrm{N}$-fertilization may be attributed to the increase in $\mathrm{N}$ uptake which positively influenced photosynthesis process indirectly, which in turn was reflected on top and root growth and consequently on ultimately enhancing higher yield Shafika and EL-Masry (2006).

Concerning the interaction effect among humic acid substances as foliar application and nitrogen fertilization data collected in Table (5) and Figs.(2\&3), it is clear that the highest top, root and sugar yields recorded $9.114,28.17$ and 5.157 tons/ fed. in the $1^{\text {st }}$ season, as well as $7.733,23.47$ and 4.393 tons/ fed in the $2^{\text {nd }}$ season for top, root and sugar yields, respectively, due to the foliar application with fulvic acid and soil $\mathrm{N}$ fertilization by $72 \mathrm{~kg} \mathrm{~N} / \mathrm{fed}$.

Based on the obtained results, it could be concluded that under the condition of this work when foliar application of fulvic acid sprayed at rate $8 \mathrm{~cm} /$ Land fertilized with nitrogen as soil application at level of $72 \mathrm{~kg} /$ fed were extremely effective in increasing top, root and sugar yields/ fed as well as juice quality which in turn improved extractable sugar.

\section{References}

Arancon, N.Q., Edwards, C.A., Lee, S. and Byrne, R. 2006. Effects of humic acids from vermicomposts on plant growth. Eurasian J. Soil Biol., 42: S65-S69.

Armstrong, M.J., and Milford, G.F.J. 1985. The nitrogen nutrition of sugar beet. British Sugar Beet Review, 53: 42- 44.

Attallah, M.Z. and El Etreiby, F. 2002. The effect of compost and mineral-N on soil properties, ten sugar beet varieties and nutrient contents. Alex. Sci. Exch., 23 (1): 109-120.

Bowen, G.D. and Rovira A.D. 1999. The rhizosphere and its management to improve plant growth. Advances in Agronomy, 66, 1-102.

Bronson, K.F., Singh, U., Neu, H.U., Abao, E.B. 1997. Automated chamber measurements of methane and nitrous oxide flux in a flooded rice soil: Fallow period emissions. Soil Sci. Soc. Am. J., 61: 988-993.

Campitelli, P.A., Velasco, M.I. and Ceppi, S.B. 2006. Chemical and physic- 
chemical characteristics of humic acids extracted from compost, soil and amended soil. Plant, 69: 1234-1239.

Canellas, L.P., Olivares, F.L., OkorokovaFacanha, A.L. and Facanha, A.R. 2002. Humic acids isolated from earthworm compost enhance root elongation, lateral root emergence and plasma membrane H-ATPase activity in maize roots. Plant Physiol., 130: 1951-1957.

Chapman, H.D. and Pratt, P.F. 1961. Methods of analysis for soil, plant and water. Univ. California, Agric. Sci., $2^{\text {nd }}$ printing, 150- 179.

Chen, Y., Clapp, C.E., andMagen, H. 2004a. Mechanisms of plant growth stimulation by humic substances: The role of organic-iron complexes. Soil Science and Plant Nutrition, 50: 1089-1095.

Chen, Y., Nobili, M., and Aviad, T. 2004b. Stimulatory effect of humic substances on plant growth. In: Magdoft F., Ray R. eds): Soil Organic Matter in Sustainable Agriculture. CRC Press, Washington.

David, P.P., Nelson, P.V. and Sanders, D.C. 1994. A humic acid improves growth of tomato seedling in solution culture. $J$. Plant Nutrition, 17:173-184.

Eisa, Salwa, A. 2011. Effect of amendments, humic and amino acids on increasing soils fertility, yields and seeds quality of peanut and sesame on sandy soils Res., $J$. Agric. Biolo. Sci., 7(1): 115-125.

El-Bassiouny Hala, S.M., Bakry, A.B. Attia, A.A. and AbdAllah, M.M. 2014. Physiological role of humic acid and nicotinamide on improving plant growth, yield, and mineral nutrient of wheat (Triticum durum) grown under newly reclaimed sandy soil, Agric. Sci., 5(8): 687-700.

El-Geddawy, I.H., EL- Keraedy, M.S. Omar, A.M. and Elmoghazy, Amira E. 2008. Growth and chemical constituents of sugar beet as affected by nitrogen sources and rates and boron fertilizer.
Meeting on the Challenges of Sugar Crops and Integrated Industries in Developing Countries. AL Arish, Egypt. pp 75-82.

El-Sarag, E.I. 2009. Maximizing sugar beet yield, quality and water use efficiency using some agricultural practices in North Sinai conditions. Bull. Fac. Agric., Cairo Univ., 60: 155-167.

Ferweez, H., Ibrahim, M. F. M. and Allan A. M. 2011. Improving yield and quality of sugar beet using boron at different levels of nitrogen fertilizer. Alex. Sci., Exch., 32(1) 51-57.

Harley, S. 2015. humic-or-fulvic-acid-whatkind-are-your-plants-on/ http://maximumyield.com/blog.

Hye, Y.S., Kil, S.Y. and Sang, G.S. 2014. Effect of foliar application of fulvic acid on plant growth and fruit quality of tomato (Lycopersicon esculentum L.) Horticulture, Environ. Biotechnol., 55(6): 455-461.

Ibrahim Dina, S.S., Nour El-Deen,A. E. K. and A. Fatma, M.M. 2013. Induction of systemic resistance in sugar beet infected with Meloidogyne incognita by humic acid, hydrogen peroxide, thiamine and two amino acids, Egypt. J. Agronematol., 12(1): 22-41.

Kabeel, H., Abd El- F.M. atif and Baza, M.S.M. 2008.Growth, fruiting and nutritional status of "Le-Conte" pear trees in response to mineral and humate fertilizers. Annals of Agric. Sci. Moshtohor, 46(2): 139-156

Kennedy, I.R. and Tchan, Y.T. 1992. Biological nitrogen fixation in nonleguminous field crops, Recent Advances. Plant Soil, 141: 93-1.

Khaled, H. and Fawy, H.A. 2011. Effect of different levels of humicacids on the nutrient content, plant growth, and soil properties under conditions of salinity. Soil and Water Res., 6: 21-29.

Ladha, J.K., de Bruijn, F.J., and Malik, K.A. 
1997. Introduction: Assessing opportunities for nitrogenfixation in rice. A frontier project. Plant Soil, 194: $1-10$.

Mackowiak, C.L., Grossl, P.R., and Bugbee, B.G. 2001.Beneficial effects of humic acid on micronutrient availability to wheat. Soil Science Society of America J., 56: 1744-1750.

McGinnus, R.A. 1971.Sugar beet technology, 2nd edn.sugar beet development foundation, Fort., Color, U.S.A.

Mehran, S. and Samad, S. 2013.Study of potassium and nitrogen fertilizer levels, on the yield of sugar beet in jolge cultivar. J. Novel Appl. Sci., 2(4):94100.

Mekdad, A.A. 2015. Sugar Beet Productivity As Affected By Nitrogen Fertilizer and Foliar Spraying With Boron. Int. J. Curr. Microbiol. Appl. Sci., ISSN: 2319-7706 Volume 4 Number 4 pp. 181-196.

Moustafa, Shafika, N. 2006. Response of some sugar beet varieties to methanol and methods of nitrogen fertilizer applications. Annals of agri. Sc., Moshtohor, vol. 44 (1): 89-100.

Moustafa, Shafika, N. and EL-Masry, A.A. 2006.Effect of nitrogen and potassium fertilization with or without spraying by iron combined with manganese on some physio-chemical properties, productivity and yields of sugar beet crop. Annals of Agri. Sci., Moshtohor, 44 (4): 14311446.
Nardi, S., Pizzeghello, D. Muscolo, A. and Vianello, A. 2002. Physiological effects of humic substances on higher plants. Soil Biology and Biochemistry, 34: 1527-1536.

Ramadan, A.A. 2015. Effects on growth, yield, root quality and anatomy in sugar beet)Beta vulgaris L.) using a mixture of yeasts and organic manure asan alternative to mineral $-\mathrm{N}$ fertilizer $J$. Biotechnol. Sci., 3-II(Published onlinehttp://jbs.darsgah-e-ahlebait.com.

Seydabadi, A. and Armin, M. 2014. Sugar beet (Beta vulgaris L.) response to herbicide tank-mixing and humic acid. Int. J. Biosci., (IJB), 4 (12): 339-345.

Shaban, KH.A.H. and Abdel Fatah, Eman, M. and Syed, Dalia, A. 2014. Impact of humic acid mineral nitrogenfertilization on soil chemical properties, yield and quality of sugar beet under saline soil. $J$. Soil Sci. and Agric. Eng., Mansoura Univ., 5 (10): 1317-1335.

Shrestha, R.K. and Ladha, J.K. 1998. Nitrate in groundwater and integration of nitrogen-catch-crop in rice-sweet pepper cropping system. Soil Sci. Soc. Am. J., 62: 1610-1619.

Snedecor, G.W. and Cochran, W.C. 1980.Staticallymethods. $6^{\text {th }}$ Ed. Lowa State Univ. Press, AmestIowa U.S.A...

Steinberg, C.E.W., Meinelt, Timofeyev, Bittner, T.M.A. and Menzel, M.R. 2008.Humic Substances (review series. Part 2: Interactions with Organisms, Environ. Sci. Pollu. Res., 15: 128-135.

\section{How to cite this article:}

El-Hassanin, A.S., M.R. Samak, Moustafa, N. Shafika, A.M. Khalifa and Ibrahim Inas, M. 2016. Effect of Foliar Application with Humic Acid Substances under Nitrogen Fertilization Levels on Quality and Yields of Sugar Beet Plant. Int.J.Curr.Microbiol.App.Sci. 5(11): 668680. doi: http://dx.doi.org/10.20546/ijcmas.2016.511.078 